\title{
PENGARUH PEMBERIAN TERAPI MUSIK GAMELAN JAWA TERHADAP TINGKAT KECEMASAN LANSIA
}

\author{
Utami Dwi Yusli ${ }^{1}$, Nurullya Rachma ${ }^{2}$ \\ ${ }^{1}$ Departemen Ilmu Keperawatan, Fakultas Kedokteran, Universitas Diponegoro \\ ${ }^{2}$ Divisi Keperawatan Jiwa dan Komunitas, Departemen Ilmu Keperawatan, Fakultas Kedokteran, \\ Universitas Diponegoro \\ nurullyarachma@fk.undip.ac.id
}

\begin{abstract}
Abstrak
Kecemasan lansia di panti wreda cenderung meningkat setiap hari. Kondisi ini dapat mengakibatkan ketidakmampuan berlebihan dan gangguan pada kualitas kehidupan lebih lanjut pada lansia. Terapi musik gamelan adalah salah satu alternatif terapi pada lansia dengan kecemasan, terutama kecemasan ringan sampai sedang yang sangat mudah untuk dilakukan dan tanpa efek samping. Penelitian ini bertujuan untuk mengetahui pengaruh terapi Musik Gamelan Jawa terhadap kecemasan pada lansia di Rumah Pelayanan Sosial Lanjut Usia Pucang Gading Semarang. Metode penelitian yang digunakan adalah penelitian kuantitatif dengan quasi experiment design dengan rancangan pretest-postest one group design. Teknik sampling yang digunakan adalah purposive sampling dengan jumlah sampel 40 responden. Pengambilan data menggunakan lembar kuesioner Geriatric Anxiety Scale (GAS). Hasil penelitian menunjukkan bahwa ada pengaruh terapi musik gamelan jawa terhadap tingkat kecemasan Lansia di Rumah Pelayanan Sosial Lanjut Usia Pucang Gading Semarang dengan nilai $p$ value 0,000. Terapi musik gamelan dapat menjadi salah satu alternatif intervensi keperawatan yang dapat dilakukan oleh para caregiver di panti wreda untuk dapat dimplementasikan kepada lansia dengan masalah kecemasan.
\end{abstract}

Kata kunci: Musik gamelan, lansia, kecemasan

\begin{abstract}
The effect of javanese gamelan music therapy intervention on elderly anxiety level. Elderly anxiety level in nursing homes tend increase every day. This condition can lead to excessive incompetence and further interference in quality of life. Gamelan music therapy is an alternative therapy management in the elderly with anxiety. It can control mild to moderate anxiety level which is very easy to do without side effects. The purpose of this study was to determine the effect of javanese gamelan music therapy intervention on elderly anxiety level at Elderly Social Services Home of Pucang Gading Semarang. The method of this study was quantitative used quasi-experimental design with pretest-posttest one group design. Sampling technique used was purposive sampling with 40 respondents as the sample. Retrieving data using a Geriatric Anxiety Scale (GAS) questionnaire sheet. The results show that there was a significant influence of Javanese gamelan music therapy on anxiety level of the Elderly at Elderly Social Services Home of Pucang Gading Semarang with $p$ value of 0.000. Gamelan music therapy can be an alternative nursing intervention and can be done by the care giver in a nursing home for elderly with anxiety problems.
\end{abstract}

Keywords: Gamelan music, elderly, anxiety

\section{Pendahuluan}

Lansia merupakan tahap akhir pada siklus kehidupan dengan munculnya tandatanda penuaan (Pusat Data dan Informasi, 2016). Pada masa ini banyak permasalahan yang dapat terjadi pada lansia yaitu, masalah, ekonomi, mental, sosial, pekerjaan, dan kesehatan (Demartoto, 2006) (Wong, 2008). Masalah kesehatan pada lansia karena penurunan fungsi fisiologis ditandai dengan munculnya masalah degeneratif. Masalah kesehatan dapat menurunkan daya tahan tubuh, membuat lansia rentan terkena infeksi penyakit menular (Pusat Data dan Informasi, 2016). Lansia juga dapat mengalami masalah kesehatan mental yang dapat dihubungkan dengan sejumlah faktor risiko psikososial seperti penurunan fungsi kognitif, kehilangan peran sosial, kehilangan keluarga, isolasi sosial, serta berkurangnya interaksi sosial (Tamher S, 2009) (Kemkes RI, 2016). Masalah lansia juga dipengaruhi oleh lingkungan yang 
berbeda, misalnya tempat tinggal. Beberapa masalah dapat muncul pada lansia yang tinggal di panti wreda (Pusat Data dan Informasi, 2016).

Lansia yang tinggal di panti wreda memiliki latar belakang kehidupan dan alasan yang berbeda-beda. Hal ini bisa menjadi stresor atau sumber stres setiap lansia di panti wreda (Pusat Data dan Informasi, 2016). Sumber stres tersebut dipengaruhi oleh berbagai faktor, antara lain lingkungan, sosial, dan hidup tanpa keluarga yang dapat menyebabkan munculnya perubahan dan respon psikologis, seperti kognisi, perilaku sosial, dan emosi. Emosi yang dekat dengan stres adalah kecemasan. Kecemasan adalah respon psikologis, tingkah laku, dan emosi terhadap stres (Junaidi \& Noor, 2010) (Setyawan, M F., 2013) (Wiyono \& Widodo, 2010).

Kecemasan lansia yang tinggal di panti wreda disebabkan oleh penurunan kondisi fisik, mental, paparan terhadap kematian yang meningkat, serta dukungan sosial yang berangsur-angsur menurun karena jauh dari keluarga (Mumpuni, 2014). Para lansia di Rumah Pelayanan Sosial Pucang Gading Semarang, menceritakan perasaan yang dialami, yaitu rasa takut atau khawatir terhadap kematian, penyakit yang dapat dialami, pendapatan atau penghasilan, kehidupan yang akan datang, usia lanjut tanpa ditemani anak karena tidak mempunyai anak, dan terjatuh pada saat berjalan. Perasaan tersebut biasanya disebabkan karena teringat anak dan istri di rumah, penyakit hipertensi atau penyakit lain yang sedang dialami, mimpi terjatuh, tidak mempunyai anak dan istri, penghasilan setiap hari, masa mendatang, dan kelelahan yang sering terjadi.

Kecemasan lansia di panti wreda, cenderung meningkat setiap hari, dan kondisi ini dapat mengakibatkan ketidakmampuan berlebihan dan gangguan pada kualitas kehidupan lebih lanjut pada lansia (Junaidi \& Noor, 2010) (Maas, 2011). Menurut Hocking \& Koening, penanganan kecemasan pada lansia umumnya menggunakan obat psikotropik, namun penanganan tersebut dapat menimbulkan risiko seperti penurunan pemulihan fisik, ketergantungan, dan sindroma pemutusan obat (Maas, 2011). Manfaat dan risiko pengobatan tersebut harus dipertimbangkan dengan penanganan lain. Pemberian terapi yang tidak berhubungan dengan obat harus diutamakan terutama untuk pasien dengan tingkat kecemasan ringan sampai sedang, misalnya dengan kegiatan spiritual, mass age, hipnotis, dan teknik relaksasi (Maas, 2011) (Sholeh, 2011).

Berdasarkan National Safety Council terdapat bermacam-macam teknik relaksasi untuk kecemasan, yaitu teknik napas dalam, relaksasi 5 jari, dan teknik distraksi yaitu imajinasi dan terapi musik (Junaidi \& Noor, 2010). Menurut Indonesia Hypnosis Assotiation teknik ini berperan dalam pelepasan perasaan individu pada masalah emosional, memunculkan suasana hati yang positif, membantu pemecahan masalah, dan memperbaiki konflik pribadi (Daryani, 2014). Menurut Purwadi, musik mempunyai kekuatan untuk mengobati penyakit dan ketidakmampuan yang dialami setiap individu, karena saat musik diaplikasikan menjadi terapi, musik dapat meningkatkan, memulihkan, memelihara kesehatan fisik, spiritual, emosional, dan meningkatkan kesehatan psikologis (Widiastuti, 2013) (Sari, PR. dkk, 2013) (Wendy L.dkk, 2002). Tujuan penelitian ini adalah untuk mengetahui pengaruh pemberian terapi music gamelan jawa terhadap tingkat kecemasan lansia di panti wreda.

\section{Metode}

Jenis penelitian ini adalah quasi eksperiment. Rancangan yang digunakan dalam penelitian ini adalah one group pretest- posttest design. Populasi dalam penelitian ini adalah lansia dengan tingkat kecemasan ringan hingga sedang di Rumah Pelayanan Sosial Lanjut Usia Pucang Gading Semarang. Besar sampel dalam 
penelitian ini adalah 40 orang dengan teknik pengambilan sampel purposive sampling. Variabel bebas dalam penelitian ini adalah terapi musik gamelan jawa, sedangkan variabel terikat dalam penelitian ini adalah tingkat kecemasan lansia. Alat penelitian yang digunakan adalah Geriatric Anxiety Scale $(G A S)$ yang telah dilakukan alih bahasa oleh Sang Ayu Ketut Candrawati dan digunakan pada penelitiannya. Pengambilan data pretest dan posttest dilakukan pada Bulan Mei 2018. Analisa data dalam penelitian ini yaitu analisa univariat dalam penelitian ini dilakukan untuk mengetahui distribusi persentase tiap variabel. Analisa bivariat dalam penelitian ini adalah untuk mengetahui apakah ada pengaruh pembeian terapi musik gamelan jawa terhadap tingkat kecemasan lansia. Peneliti menggunakan uji bivariat dengan menggunakan uji beda 2 mean dependen yaitu T-test karena data terdistribusi normal hasil uji dependen $T$-test nilai $\mathrm{p}=$ 0.000 .

\section{Hasil}

Tabel 1.

Usia responden $(n=40)$

\begin{tabular}{|c|c|c|}
\hline Karakteristik & $\mathrm{F}$ & $\%$ \\
\hline \multicolumn{3}{|l|}{ Usia } \\
\hline 45-59 tahun & 2 & 5 \\
\hline 60-74 tahun & 25 & 62,5 \\
\hline 75-90 tahun & 12 & 30 \\
\hline$>90$ tahun & 1 & 2,5 \\
\hline \multicolumn{3}{|l|}{ Jenis Kelamin } \\
\hline Laki-laki & 16 & 40 \\
\hline Perempuan & 24 & 60 \\
\hline \multicolumn{3}{|l|}{ Lama tinggal } \\
\hline$<2$ tahun & 18 & 45 \\
\hline$\geq 2$ tahun & 22 & 55 \\
\hline
\end{tabular}

Tabel 2.

Tingkat kecemasan Lansia sebelum dilakukan Terapi Musik Gamelan Jawa (n=40)

\begin{tabular}{ccccccc}
\hline Tingkat kecemasan & $\mathrm{f}$ & $\%$ & Mean & Min & Max & SD \\
\hline Ringan & 32 & 80 & 29,82 & 21 & 55 & \multirow{2}{*}{10,20} \\
Sedang & 8 & 20 & & & & \\
\hline
\end{tabular}

Tabel 3.

Tingkat Kecemasan lansia sesudah dilakukan Terapi Musik Gamelan Jawa $(n=40)$

\begin{tabular}{ccccccc}
\hline Tingkat kecemasan & $\mathrm{f}$ & $\%$ & Mean & Min & Max & SD \\
\hline Minimal & 23 & 57,5 & & & & \\
Sedang & 4 & 10 & 20,87 & 10 & 45 & 9,95 \\
Ringan & 13 & 32,5 & & & & \\
\hline
\end{tabular}


Tabel 4.

Pengaruh Terapi Musik Gamelan Jawa terhadap tingkat kecemasan lansia $(n=40)$

\begin{tabular}{lccccr}
\hline & Mean & $\begin{array}{c}\text { Std. } \\
\text { Deviation }\end{array}$ & $\mathrm{t}$ & $\mathrm{df}$ & $\begin{array}{c}\text { Sig. (2- } \\
\text { tailed) }\end{array}$ \\
\hline Kecemasan Lansia Sebelum Terapi & 29,82 & 10,20 & 22,362 & 38 &, 000 \\
Musik Gamelan Jawa & 20,87 & 9,95 & & & \\
Kecemasan Lansia Sesudah Terapi & & & & & \\
Musik Gamelan Jawa & & & & & \\
\hline
\end{tabular}

Tabel 8 menunjukkan nilai sig.(2tailed) nilai probabilitas dalam uji $\mathrm{T}$ - test adalah .000. melihat hasil nilai sig.(2tailed) dibandingkan dengan taraf signifikasi 5\% (0,05), maka sig.(2- tailed) $<0,05$, maka terdapat perbedaan yang signifikan antara kecemasan lansia sebelum dan sesudah diberikan terapi musik gamelan jawa. Dapat dikatakan bahwa ada pengaruh terapi musik gamelan jawa terhadap tingkat kecemasan lansia di Rumah Pelayanan Sosial Lanjut Usia Pucang Gading Semarang.

\section{Pembahasan}

Hasil penelitian ini menunjukkan bahwa terdapat pengaruh pemberian terapi musik gamelan jawa terhadap tingkat kecemasan lansia. Berdasarkan hasil uji $T$ test nilai probabilitas .0001 yaitu lebih kecil $<0,05$ maka terdapat perbedaan yang signifikan antara kecemasan lansia sebelum dan sesudah diberikan terapi musik gamelan jawa. Berdasarkan hasil penelitian ini, dapat dikatakan bahwa terapi musik mempengaruhi penurunan gejala-gejala tersebut. Lansia yang mengalami gejala somatik seperti kadangkadang merasa sakit perut sebanyak 23 lansia $(57,5 \%)$ turun menjadi tidak merasakan sakit perut sebanyak 15 lansia $(37,5 \%)$, dan kadang-kadang merasa lelah sebanyak 23 lansia $(57,5 \%)$ turun menjadi tidak merasa lelah sebanyak 15 lansia $(37,5 \%)$. Penggunaan musik dapat membantu penurunan ketegangan otot dan kecemasan (Junaidi \& Noor, 2010). Pada bagian otot, penggunaan musik yang dikenal dan disukai dapat menurunkan sekresi asam laktat dan zat-zat kimia sehingga rasa sakit atau nyeri yang disebabkan oleh kecemasan dapat berkurang (Junaidi \& Noor, 2010).

Lansia yang mengalami gejala kognitif seperti kadang-kadang merasa linglung sebanyak 22 lansia $(55 \%)$ turun menjadi tidak sama sekali merasa linglung sebanyak 19 lansia (60\%), kadang-kadang tidak bisa mengendalikan kekhawatiran sebanyak 21 lansia $(52,5 \%)$ turun menjadi tidak pernah sama sekali sebanyak 15 lansia (37,5\%). Mendengarkan musik dapat mensinkronisasi ritme tubuh dengan cara adanya fibrasi serta menstimulasi seseorang untuk merasakan ketenangan (Pratiwi, 2008). Selanjutnya, menikmati musik akan menekan pengeluaran hormon kortisol atau hormon stres sehingga lambat laun pembentukan imunitas tidak terganggu. Peningkatan imunitas ini adalah dengan cara meningkatkan opiat endogen (endorfin dan enkefalin) serta menurunkan katekolamin sehingga daya tahan tubuh penderita meningkat. Kemudian mekanisme terciptanya kenyamanan jiwa, ketika telinga kita menangkap suara musik yang lembut dapat memperlambat detak jantung, memperluas kerja nafas dan akhirnya menyamankan jiwa (Junaidi \& Noor, 2010).

Rasa nyaman yang timbul pada saat mendengarkan musik dapat diakibatkan karena kelenjar hipofisis melepaskan endorfin, yang terjadi akibat aktivitas elektrik yang tersebar di regio-regio otak yang berhubungan dengan sistem limbik dan pusat kontrol otonomi. Sehingga, mendengarkan musik yang disukai membuat seseorang akan merasa lebih santai dan akhirnya bisa menurunkan ketegangan dan kecemasan terhadap 
stressor yang dihadapi (Junaidi \& Noor, 2010).

Jenis musik yang digunakan pada penelitian adalah musik gamelan jawa nada laras slendro yang mempunyai alunan lembut, menenangkan, dan sesuai dengan lansia (Shalehuddin M, 2010). Mendengarkan musik tempo lamban atau sekitar 60-100 bpm dapat memperlambat dan menyeimbangkan gelombang otak yang menandakan ketenangan (Shalehuddin M, 2010) (Suryana, 2012) (Schou, 2008). Hal ini terjadi karena dengan stimulasi binaural-beat dapat mendorong seseorang untuk kembali kedalam kesadaran (Junaidi \& Noor, 2010) (Salve, HR., \& Prabowo, 2007). Pada studi yang dilakukan oleh Raymond Bahr dalam waktu satu setengah jam mendengarkan musik yang lembut memiliki efek terapi yang sama seperti dengan menggunakan obat penenang Valium $10 \mathrm{mg}$ (IHA, 2010).

Musik antara 56 sampai 60 beat per detik dapat digunakan untuk melatih relaksasi dan gelombang otak menuju kekeadaan alfa (Salve, HR., \& Prabowo, 2007). Campbell menjelaskan bahwa musik dapat menyeimbangkan gelombang otak. Gelombang otak dapat dimodifikasi oleh musik ataupun suara yang ditimbulkan sendiri. Kesadaran terdiri atas gelombang beta, yang bergetar dari 14 hingga 20 hertz. Ketenangan dan kesadaran yang meningkat dicirikan oleh gelombang alfa, yang daurnya mulai 8 hingga 13 hertz. Periode-periode puncak kreativitas, meditasi dan tidur dicirikan oleh gelombang theta, dari 4 hingga 7 hertz. Tidur nyenyak, meditasi yang dalam, serta keadaan tak sadar menghasilkan gelombang delta, yang berkisar dari 0,5 hingga 3 hertz. Semakin lambat gelombang otak, semakin santai, puas, dan damailah perasaan (Dewi, 2009). Keadaan tenang yang dirasakan seseorang akan memiliki substansi yang memiliki beta karbolin, yaitu antagonis GABA yang menyebabkan penurunan jumlah down regulator receptor GABA. Penurunan ini yang akan mengurangi hambatan terhadap timbulnya kecemasan (Sholeh, n.d.).

Dampak lain yang dialami oleh lansia ketika mendengarkan musik gamelan laras slendro yaitu, meningkatnya produksi endorphin dan dopamine yang akan menstimulasi system limbic yang merupakan pusat pengaturan emosi untuk menghasilkan emosi yang positif yaitu bahagia dan rileks (Dong Soo Kim, 2011) (Salve, HR., \& Prabowo, 2007). Hal tersebut dapat merangsang saraf parasimpatis untuk mendilatasi pembuluh darah sehingga terjadi penurunan tekanan darah. Dong Soo Kim dalam penelitiannya pada pasien post stroke, terapi musik memberikan efek dalam menurunkan depresi dan kecemasan pasien (Mulyawati \& Erawati, 2012).

Responden mendapat terapi musik gamelan jawa nada laras slendro sebanyak 3 kali dalam 3 hari berturut-turut, dengan lama pemberian terapi selama 30 menit untuk setiap kali intervensi. Hasil dari penelitiaan Wendy L. Magee di London juga menyimpulkan bahwa musik terapi yang diberikan dalam jangka waktu yang singkat dapat memberikan perubahan yang positif pada mood seseorang (Widiastuti, 2013). Durasi yang seringkali diberikan pada saat melakukan terapi musik adalah selama 20-35 menit, tetapi untuk masalah kesehatan yang lebih spesifik terapi musik diberikan dengan durasi 30 menit sampai 45 menit (Suryana, 2012) (Schou, 2008).

\section{Simpulan dan Saran}

Ada pengaruh pemberian terapi musik gamelan jawa terhadap tingkat kecemasan lansia di Rumah Pelayanan Sosial Lanjut Usia Pucang Gading Semarang ( nilai $\mathrm{p}=$ 0.0001). Terapi musik gamelan jawa ini dapat digunakan sebagai terapi alternatif dalam penanganan kecemasan pada lansia, sehingga lansia dengan kecemasan mendapatkan penatalaksaan yang tepat. 
Daftar Pustaka

Daryani. (2014). Pengaruh Terapi Musik Langgam Jawa Terhadap Penurunan Tingkat Kecemasan Pada Lansia Di Purworejo. Jurnal Ilmu Keperawatan, 9(1), 1-12. Retrieved from http://ejournal.stikesmukla.ac.id/ind ex.php/triage/article/view/187

Demartoto, A. (2006). Pelayanan Sosial Non Panti Bagi Lansia Suatu Kajian Sosiologis. Surakarta: Sebelas Maret University Press.

Dewi, M. P. (2009). Studi Metaanalisis : Musik Untuk Menurunkan Stres, 36(2), 106-115.

Dong Soo Kim, D. (2011). Effects of Music Therapy on Mood in Stroke Patients. Yonsei Med J, (6)(52), 977-981.

IHA. (2010). Indonesia Hypnosis Assosiation. Retrieved from http://www.hipnoterapi.asia/terapi_ musik.htm

Jakarta: Kementrian Kesehatan Republik Indonesia. (2016). Pelayanan Dan Peningkatan Usia Lanjut. Retrieved October 14, 2017, from http://www.depkes.go.id/Article/Vi ew/15052700010/Pelayanan-

Danpeningkatankesehatan-UsiaLanjut

Jakarta: Pusat Data Dan Informasi Kementrian Kesehatan Republik Indonesia. (n.d.). Gambaran Kesehatan Lanjut Usia Di Indonesia. Retrieved October 14, 2017, from http://www.pusdatin.kemkes.go.id/ Folder/View/01/StructurePublikasi-Pusdatin-Buletin.Html

Junaidi., Noor, Z. (2010). Penurunan Tingkat Kecemasan Pada Lansia Melalui Terapi Musik Langgam
Jawa. Jurnal Keperawatan

Indonesia, 13(3), 195-201. Retrieved from http://jki.ui.ac.id/index.php/jki/artic le/view/252/453

Maas, M. (2011). Asuhan Keperawatan Geriatrik. Jakarta: EGC.

Mulyawati, Y., \& Erawati, M. (2012). Kombinasi musik gamelan serta senam lansia untuk lansia dengan hipertensi, 87-93.

Mumpuni, D. (2014). Analisis FaktorFaktor Psikologis Yang Mempengaruhi Death Anxiety. Skripsi.

Noor, Z., \& Junaidi. (2010). Penurunan Tingkat Kecemasan Pada Lansia Melalui Terapi Musik Langgam Jawa. Jurnal Keperawatan Indonesia, 13(3), 195-201.

Pratiwi, R. P. (2008). Terapi Musik. Retrieved from http://siarindonesia.net/utty/2008/1 0/15/terapimusik/

Pusat Data Dan Informasi, I. K. (2016). Situasi Lanjut Usia (Lansia) Di Indonesia. Retrieved October 13, 2017 , from http://www.depkes.go.id/Resources /Download/Pusdatin/Infodatin/Info datin lansia 2016.Pdf

Salve, HR., \& Prabowo, H. (2007). Treatment Metamusic untuk Menurunkan Stress (Tesis Pasca Sarjana). Jakarta: Universitas Gunadarma, Jakarta.

Sari, PR., Purwanta., Aulawi, K. (2013). Pengaruh Terapi Musik Jawa Terhadap Kecemasan Lansia Dengan Hipertensi Di Posyandu Lansia Kusumasari Blimbingsari Yogyakarta. Skripsi. 
Schou, K. (2008). Music Therapy For Post Operative Cardiac Patients, A Randomized Controlled Trial Evaluating Guided Relaxation With Music And Music Listening On Anxiety, Pain, And Mood Dissertation Thesis. Department Of Communication: Aalborg University.

Setyawan, M F., S. (2013). Hubungan Spiritualitas dengan tingkat kecemasan menghadapi kematian Lansia Umur di Atas 60 Tahun di Dusun Tanggulangin, Pandean, Ngablak, Magelang, Jawa Tengah, 5. Retrieved from http://digilib.unisayogya.ac.id/628/ 1/NASKAH PUBLIKASI.pdf

Shalehuddin M. (2010). Pengaruh Terapi Musik Gamelan Jawa Terhadap Depresi Pada Lansia di UPT Pelayanan Sosial Lansia Pasuruan (Tesis Pasca Sarjana). Universitas Airlangga, Surabaya.

Sholeh, M. (n.d.). Tahajud, terapi religius : Manfaat praktis ditinjau dari ilmu kedokteran. 2005. Yogyakarta: Pustaka Pelajar.

Sholeh, M. (2011). Perkembangan Psikologi.

Suryana, D. (2012). Terapi Musik (cetakan be). W site.
Tamher S, N. (2009). Kesehatan Usia Lanjut Dengan Pendekatan Asuhan Keperawatan. Jakarta: Salemba Medika.

Wendy L.dkk. (2002). The Effect of Music Therapy on Mood State in Neurological Patients. Journal of Music Therapy XXXIX. A Pilot Study. American Music Therapy Association.

Widiastuti, R. (2013). Pengaruh Intervensi Musik Gamelan Terhadap Depresi Pada Lansia Di Panti Wreda Harapan Ibu, Semarang. Jurnal Keperawatan Komunitas, 1(2), 135-140. Retrieved from http://jurnal.unimus.ac.id/index.php /JKK/article/view/991

Wiyono, W., Widodo, A. (2010). Hubungan Antara Tingkat Kecemasan Dengan Kecenderungan Insomnia Pada Lansia Di Panti Wredha Dharma Bhakti Surakarta. Berita Ilmu Keperawatan, 2(2), 87-92. Retrieved from https://publikasiilmiah.ums.ac.id/ha ndle/11617/2042

Wong, D. L. (2008). Buku Ajar Keperawatan Pediatric. Jakarta: EGC. 